\title{
TINGKAT PARTISIPASI MASYARAKAT TERHADAP KAWASAN KONSERVASI PERIKANAN (RESERVAT) LUBUK MANIK KABUPATEN BUNGO PROVINSI JAMBI.
}

\author{
Yuyun Sutia $^{1}$, Syafrialdi ${ }^{2}$ Djunaidi $^{2}$ \\ ${ }^{1}$ Alumni Program Studi Pemanfaatan Sumberdaya Perikan Fakultas Perikanan \\ ${ }^{2}$ Dosen Program Studi Pemanfaatan Sumberdaya Perikan Fakultas Perikanan \\ Universitas Muara Bungo
}

\begin{abstract}
ABSTRAK
Perairan Sungai Batang Bungo merupakan salah satu sungai utama di Kabupaten Bungo dan merupakan bentuk perairan yang terbuka dan panjang mencapai kurang lebih $50 \mathrm{~km}$. Rantau Pandan, desa yang memiliki kawasan konservasi perikanan (Reservat) lubuk larangan salah satunya yaitu : Reservat Lubuk Manik. Waktu penelitian dilaksanakan selama 4 (empat) bulan, tahap persiapan dan survei dilakukan bulan September-Oktober 20017 dan dilanjutkan dengan pengolahan data bulan November-Desember 2017. Tujuan penelitian ini adalah untuk mengetahui tingkat partisipasi masyarakat Kecamatan Rantau Pandan terhadap keberadaan Kawasan Konservasi Perikanan (Reservat) Lubuk Manik. Metode Penelitian Tingkat Partisipasi Masyrakat Terhadap Kawasan Konservasi Perikanan (Resevat) Kabupaten Bungo adalah metode survey dan wawancara langsung, dengan cara mengambil sampel secara acak, sampel atau reponden diambil secara acak dengan menggunakan SWOT terhadap Kawasan Konservasi Perikanan (Resevat).

Hasil penelitian menunjukan bahwa Tingkat Patisipasi masyarakat umum dengan melibatkan 80 orang responden untuk pengelolaan Kawasan Konservasi kategori rendah dengan nilai 1685 dalam persentase (21,06\%), Tingkat partisipasi Pemangku Kepentingan dengan jumlah responden sebanyak 20 orang responden dimana tingkat partisipasi dalam kategori rendah dengan nilai partisipasi sebesar 622 dengan persentase sebesar $(31,1 \%)$.
\end{abstract}

Kata Kunci : Partisipasi dan Kawasan Konservasi perairan (Reservat) 
SEMAH : Journal Pengelolaan Sumberdaya Perairan VOL. 3 No. 1

April 2019

\section{PENDAHULUAN}

Perairan Sungai Batang Bungo merupakan salah satu sungai utama di Kabupaten Bungo dan merupakan bentuk perairan yang terbuka dan panjang mencapai kurang lebih $50 \mathrm{~km}$. Kecamatan Rantau Pandan memiliki luas area 239,61 $\mathrm{km}^{3}(5,14 \%$ dari luas wilayah Kabupaten Bungo 4.659 $\mathrm{km}^{2}$ ) yang terdiri dari 6 desa/kelurahan. Sungai yang melintasi kecamatan ini adalah Sungai Batang Bungo (Bungo dalam Angka, 2015). Rantau Pandan, desa yang memiliki kawasan konservasi perikanan (Reservat) lubuk larangan salah satunya yaitu : Reservat Lubuk Manik.

Berdasarkan observasi yang telah dilakukan diketahui bahwa penangkapan ikan di Zona Ekonomi Kawasan Konservasi Perikanan (Reservat) dilakukan setiap saat oleh nelayan setempat dan mendapatkan hasil yang cukup baik. Setiap tahun dilakukan penyebaran benih (Restoking) ikan semah, gurami, dan lampam (Puntius schwanefeii). Upaya pelestarian sumberdaya ikan dan ekosistemnya berkelanjutan dapat bermanfaat bagi masyarakat, maka perlu dilakukan upaya konservasi. Bentuk konservasi yang dilakukan masyarakat adalah Suaka Perikanan dalam kearifan lokal karena mereka memiliki aturan adat atau nagari dalam pengelolaannya ( Kurniasari,dkk, 2013). Selain itu, suaka
ojs.umb-bungo.ac.id/index-php/SEMAHJPSP ISSN : 2580-0736

perikanan merupakan cara pengelolaan sumberdaya perikanan yang efektif dan efisien, karena secara langsung dapat melindungi dan meningkatkan sumber daya perikanan (Ardimansyah, 2011).

Reservat atau dengan kata lain Suaka perikanan merupakan suatu ekosistem perairan yang memiliki daerah yang terbatas. Kegiatan penangkapan di perairan tersebut dilarang dengan cara apapun, kapanpun dan oleh siapapun, karena fungsinya sebagai tempat pelestarian ikan-ikan endemik yang langka (atau hampir punah) dan beberapa spesies yang dilindungi keberadaannya. Dari kajian itu partisipasi masyarakat terhadap keberadaan Kawasan Konservasi Perikanan Lubuk Manik belum dilakukan. Berdasarkan uraian tersebut maka perlu dilakukan kajian "Tingkat Partisapasi Masyarakat Terhadap Kawasan Konservasi Perikanan (Reservat) Lubuk Manik Kabupaten Bungo"

Tujuan penelitian ini adalah untuk mengetahui tingkat partisipasi masyarakat Kecamatan Rantau Pandan terhadap keberadaan Kawasan Konservasi Perikanan (Reservat) Lubuk Manik. 
SEMAH : Journal Pengelolaan Sumberdaya Perairan VOL. 3 No. 1

April 2019

\section{METODOLOGI PENELITIAN}

Penelitian ini dilaksanakan di Kawasan Konservasi Perikanan (Reservat) Lubuk Manik, Sungai Batang Bungo, yang meliputi 4 Desa di Kecamatan Rantau Pandan, Kabupaten Bungo. Waktu penelitian dilaksanakan selama 4 (empat) bulan, tahap persiapan dan survei dilakukan bulan September-Oktober 20017 dan dilanjutkan dengan pengolahan data bulan NovemberDesember 2017. Untuk lebih jelasnya lokasi penelitian dapat dilihat pada pada Gambar 3.1 .

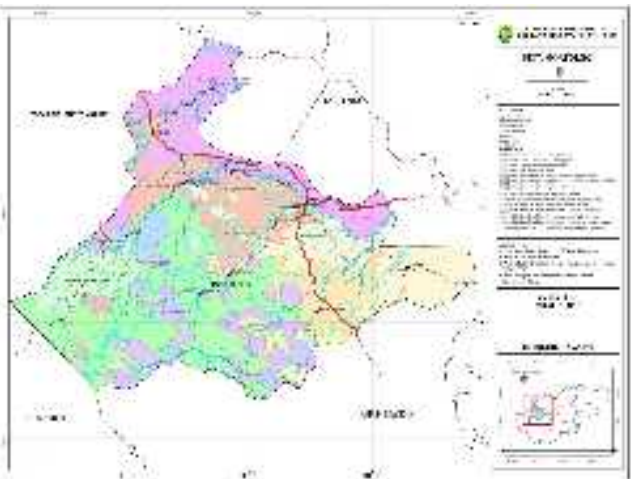

Gambar 3.1 Peta Lokasi Penelitian

Metode yang digunakan dalam Penelitian ini adalah metode survey dan wawancara langsung, dengan cara mengambil sampel secara acak, sampel atau reponden diambil secara acak dengan menggunakan SWOT terhadap Kawasan Konservasi Perikanan (Resevat).

Populasi yang diamati sebagai objek penelitian adalah Kawasan Konservasi
ojs.umb-bungo.ac.id/index-php/SEMAHJPSP ISSN : 2580-0736

Perikanan (Resevat) yang terdapat di Kecamatan Rantau Pandan Kabupaten Bungo, sedangkan sampel penelitian sebagai fokus kajian adalah tingkat partisipasi masyarakat yaitu sampel masyarakat beberapa Dusun (Dusun Rantau Pandan, Leban, Tebing Tinggi dan Dusun Rantau Duku) yang terdapat dalam Kecamatan Rantau Pandan.

Dalam menganalisis data terhadap tingkat partisipasi masyarakat terhadap Kawasan Konservasi Perikanan (Resevat), selain dilakukan dengan analisis kuantitatif juga dilakukan analisis kualititatif.

\section{HASIL DAN PEMBAHASAN}

\section{Analisis Tingkat Partisipasi Masyarakat}

\subsection{Analisis Tingkat Partisipasi Masyarakat Umum}

Berdasarkan hasil penelitian yang telah dilaksanakan dapat dijelaskan bahwa tingkat partisipasi masyarakat umum di empat dusun yang berada di Kawasan Konservasi Perikanan (Reservat) Lubuk Manik sebagai upaya konservasi perairan yang melibatkan 80 responden pada kategori Rendah dengan nilai 1685 (21,06\%). 
SEMAH : Journal Pengelolaan Sumberdaya Perairan VOL. 3 No. 1

April 2019

Berdasarkan hasil penelitian di ketahui bahwa tingkat partisipasi masyarakat di empat dusun di kecamatan Rantau Pandan terhadap keberadaan Kawasan Konservasi Perikanan (Reservat) Lubuk Manik dikategorikan rendah $(21,06)$, hasil ini dapat dari hasil kuisioner dengan 13 pertanyaan dan 5 sub pertanyaan, yang diisi oleh 80 orang responden hasilnya tidak berimbang, sebagian besar masyarakat belum memahami istilah Kawasan Konservasi Perikanan (Reservat) Lubuk Manik, keikutsertaan masyarakat dalam program pemerintah baik, keikutsertaan masyarakat dalam kegiatan gotong royong rendah. Namun terdapat faktor kelemahan seperti: partisipasi masyarakat dalam perencanaan, organisasi, berdiskusi juga rendah, keikutsertaan masyarakat dalam pelestarian lingkungan rendah, masih adanya ekploitasi yang berlebihan.

Menurut Salm dkk., (2000) Dalam upaya pengelolaan kawasan konservasi perlu diketahui persepsi masyarakat terhadap keberadaan fungsi tersebut, karena masyarakat yang memiliki persepsi yang benar akan berperilaku positif terhadap upaya-upaya konservasi.

Keberhasilan dari pengelolaan konservasi juga tergantung dari dukungan masyarakat setempat. Dukungan masyarakat merupakan tanda bahwa masyarakat setempat
ojs.umb-bungo.ac.id/index-php/SEMAHJPSP ISSN : 2580-0736

peduli terhadap konservasi, yang mendorong mereka untuk mentaati peraturan kawasan konservasi oleh masyarakat setempat.

\subsection{Analisis Tingkat Partisipasi Pemangku Kepentingan}

Berdasarkan hasil wawancara dan kuisioner dengan 13 pertanyaan dan 5 sub pertanyaan yang melibatkan 20 responden hasil penelitian menunjukan bahwa tingkat partisipasi pemangku kepentingan juga pada kategori rendah. Dengan nilai $622(31,1 \%)$.

Hasil penelitian menunjukan bahwa tingkat partisipasi Pemangku Kepentingan pada kategori Rendah, berdasarkan hasil wawancara dengan 13 pertanyaan dan 5 sub pertanyaan yang melibatkan 20 responden sebagian besar belum memahami istilah Kawasan Konservasi Perikanan (Reservat), namun disisi lain sistem pemerintahan dusun berjalan dengan baik, penegakan hukum adat sangat baik sehingga dapat meminimalisirkan terjadinya konflik. Namun juga terdapat faktor kelemahan seperti : partisipasi Pemangku Kepentingan dalam perencanaan, organisasi, berdiskusi juga rendah, Pemangku Kepentingan jarang melakukan penyuluhan kepada 
SEMAH : Journal Pengelolaan Sumberdaya Perairan VOL. 3 No. 1

April 2019

masyarakat agar selalu menjaga kelestarian lingkungan di sekitar Kawasan Konservasi Perikanan (Reservat) tersebut.

Tingginya tingkat partisipasi pemerintah dan pengelola dalam perencanaan dan kegiatan diskusi terhadap Kawasan Konservasi Perikanan (Reservat) mampu meminimalisirkan ekploitasi terhadap sumberdaya alam yang berlebihan dan mengubah paradigma keberadaan sumberdaya lingkungan yang digunakan semata-mata untuk meningkatkan kesejahteraan manusia. Maka dari itu perlu kerjasama yang baik atara masyarakat dengan pemerintah dalam melestarikan Kawasan Konservasi Perikanan (Reservat) yang ada di Kecamatan Rantau Pandan.

Menurut Rahardjo (1996) partisipasi diartikan sebagai upaya peran serta masyarakat dalam suatu kegiatan baik dalam bentuk pernyataan maupun kegiatan. Lebih lanjut dijelaskan partisipasi merupakan keikutsertaan masyarakat dalam programprogram pembangunan. Pada dasarnya partisipasi dibedakan menjadi dua, yaitu partisipasi yang bersifat swakarsa dan partisipasi yang sifat simobilisasikan. Partisipasi swakarsa mengandung arti bahwa keikutsertakan dan peran sertanya atas dasar kesadaran dan kemauan sendiri, sementara partisipasi yang dimobilisasikan memiliki arti
ojs.umb-bungo.ac.id/index-php/SEMAHJPSP ISSN : 2580-0736

keikutsertakan dan berperanserta atas dasar pengaruh orang lain.

\section{Analisis SWOT}

\subsection{Faktor Internal}

Berdasarkan hasil observasi di lokasi penelitian, pengamatan kondisi internal dari Kawasan Konservasi Perikanan (Reservat) Lubuk Manik melalui kuisioner dan wawancara dengan masyarakat di dapatkan beberapa indikator, indikator tersebut disusun dalam matriks Internal Faktor Evaluation.

Berdasarkan hasil Matriks Internal diketahui bahwa pengelolaan suaka perikan (Reservat) di Kecamatan Rantau Pandan mempunyai skor 0,374. Bahwa kondisi internal yang bersal dari dalam system masih mempunyai kekuatan untuk mengatasi masalah yang dihadapi.

Menurut Salm, et.,al (2000) pengelolaan kawasan konservasi perlu diketahu persepsi dan partisipasi masyarakat terhadap keberadaan terhadap keberadaan fungsi tersebut, karena masyarakat yang memiliki persepsi yang benar akan berprilaku positif terhadap upaya-upaya konservasi. Keberhasilan dari pengelolaan konservasi juga tergantung 
SEMAH : Journal Pengelolaan Sumberdaya Perairan VOL. 3 No. 1

April 2019

dari dukungan masyarakat setempat. Dukungan masyarakat merupakan tanda bahwa masyarakat setempat peduli terhadap konservasi, yang mendorong mereka untuk mentaanti peraturan kawasan konservasi oleh masyarakat setempat.

\subsection{Faktor Eksternal}

Dari hasil pengamatan kondisi eksternal dari Kawasan Konservasi Perikanan (Reservat) Lubuk Manik di perairan Sungai Batang Bungo di peroleh beberapa indikator, indikator tersebut disusun dalam matriks

\section{Eksternal Faktor Evaluation.}

Berdasarkan hasil analisis yang ditampilkan dalam tabel perhitungan Internal Factor dan External Factor diatas, peneliti dapat memberikan jawaban bahwa skor rata rata yang diperoleh baik internal maupun external memberikan gambaran bahwa Kawasan Konservasi Perikanan (Reservat) di perairan Sungai Batang Bungo berpotensi sebagai wisata ekologi berbasiskan kearifan lokal masyarakat.

Selain terdapat Kawasan Konservasi Perikanan (Reservat) di perairan Sungai Batang Bungo juga lokasi terdapat beberapa tempat istirahat sementara karena lokasi Kawasan Konservasi Perikanan (Reservat) dekat dengan jalan sehingga masyarakat dapat melihat biota yang terdapat kawasan konservasi perikanan (Reservat) selain itu
ojs.umb-bungo.ac.id/index-php/SEMAHJPSP ISSN : 2580-0736

juga di sekitaran Kawasan Konservasi Perikanan (Reservat) Lubuk Manik terdapat zona inti, zona penyangga dan zona ekonomi.

Faktor peluang yang perlu digunakan dalam memanfaatkan peluang adalah dengan manajemen pengelolaan yang baik, meningkatkan SDM yang berkompeten, menyatukan pandangan untuk menata arah pengelolaan potensi ekowisata serta memanfaatkan segala potensi ekowisata yang ada sehingga dapat menjadi sebuah kekuatan untuk mengembangkan Kawasan Konservasi Perikanan (Reservat) sebagai ekowisata berbasiskan kearifan lokal masyarakat dengan selalu menjalin komunikasi/ kerjasama bersama pemerintah serta berbagai pihak yang siap dan ikut terlibat didalamnya.

Menurut Setiawan et al, (2007) menyatakan bahwa suatu daerah yang mata pencaharian pelaku pada sektor perikanan jika dikelola dengan baik akan dapat memberikan kontribusi bagi sumber pendapatan di daerah tersebut. Akses jalan untuk menuju lokasi Kawasan Konservasi Perikanan (Reservat) lancar sehingga mudah dijangkau bagi para pengunjung yang 
SEMAH : Journal Pengelolaan Sumberdaya Perairan VOL. 3 No. 1

April 2019

ingin berwisata ke Kawasan Konservasi Perikanan (Reservat) Lubuk Manik. Adanya kerja sama yang baik antara pemerintah daerah dengan masyarakat dan pihak swasta dalam pengelolaan Kawasan Konservasi Perikanan (Reservat) maupun potensi perikanan budidaya di sekitar Kawasan Konservasi Perikanan (Reservat).

Kurangnya publikasi terhadap keberadaan Kawasan Konservasi Perikanan (Reservat) sehingga informasi tentang keberdaan Kawasan Konservasi Perikanan (Reservat) Lubuk Manik belum banyak diketahui masyarakat luas. Masalah serius lainya yang menjadi ancaman dikasawan Kawasan Konservasi Perikanan (Reservat) adalah degradasi lingkungan seperti pencemaran perairan atau abrasi. Pencemaran perairan akibat buangan limbah, dan penambang emas ilegal (PETI) serta limbah domestik (Fauzi dan Anna, 2010).

Tidak adanya pelatihan tentang konservasi perairan kepada masyarakat setelah Kawasan Konservasi Perikanan (Reservat) terbentuk sehingga menjadi ancaman terhadap keberadaan Kawasan Konservasi Perikanan (Reservat) karena dianggap tidak memberikan dampak ekonomis bagi sebagian masyarakat yang terganggu dengan keberadaan Kawasan Konservasi Perikanan (Reservat).
ojs.umb-bungo.ac.id/index-php/SEMAHJPSP ISSN : 2580-0736

\section{Analisis Strategi}

Berdasarkan hasil Matriks SWOT di atas dapat dijelaskan bahwa alternatif strategi yang harus dilakukan antara lain :

- Strategi Kekuatan (S) - Peluang (O) : menggunakan seluruh kekuatan untuk memaksimalkan peluang, tingkat partisipasi masyarakat yang baik merupakan kekuatan sedangkan akses jalan yang lancar merupakan peluang, maka strategi yang harus dilakukan adalah memaksimalkan peluang Kawasan Konservasi Perikanan (Reservat) Lubuk Manik sebagai tempat ekowisata periarairan yang menjadi nilai tambah ekonomis masyarakat sekitar kawasan konservasi perikanan (Reservat).

- Strategi Kekuatan (S) - Ancaman (T) : menggunakan seluruh kekuatan untuk mengatasi ancaman, keikutsertaan masyarakat dalam program pemerintah dan bantuan yang di peroleh dari pemerintah merupakan kekuatan sedangkan kurangnya publikasi, kurangnya penerapan dan tidak adanya pelatihan tentang konservasi perairan merupakan 
SEMAH : Journal Pengelolaan Sumberdaya Perairan VOL. 3 No. 1

April 2019

ancaman, alternatif strategi yang harus dilakukan adalah meningkatkan kerjasama antara masyarakat umum dan pemangku kepentingan dengan cara melakukan publikasi pelatihan tentang konservasi perairan.

- Strategi Kelemahan ( W) - Peluang(O) : menghindari kelemahan untuk memaksimalkan peluang, kebiasaan masyarakat membuang sampah sembarangan ke perairan merupakan kelemahan sedangkan kelestarian lingkungan sungai merupakan peluang bagi semua biota air yang di sungai untuk tumbuh dan berkembangbiak, maka alternatif strategi yang harus dilakukan adalah dengan cara melakukan sosialisasi kepada masyarakat agar tidak membuang samapah semabarangan ke sungai.

- Strategi Kelemahan ( W) - Ancaman (T) : menghindari kelemahan untuk meminimalkan ancaman, rendahnya keikutsertaan masyarakat dalam organisasi pengelolaan Kawasan Konservasi Perikanan (Reservat) merupakan kelemahan, sedangkan kurangnya publikasi sehingga informasi yang diterima masyarakat sering keliru dalam menanggapi keberadaan Kawasan Konservasi Perikanan (Reservat) sebagai upaya konservasi merupakan ancaman,
ojs.umb-bungo.ac.id/index-php/SEMAHJPSP ISSN : 2580-0736

maka alternatif strategi yang harus dilakukan adalah perlunya dukungan pemerintah dalam hal ini petugas penyuluh lapangan sebagai mediasi untuk melakukan pengukuhan organisasi pengelolaan Kawasan Konservasi Perikanan (Reservat) agar pengelolaan dapat efektif dan efisien.

\section{KESIMPULAN DAN SARAN}

1. Kesimpulan

Berdasarkan hasil penelitian dan pembahasan tentang tingkat partisipasi masyarakat terhadap keberadaan Kawasan Konservasi Perikanan (Reservat) Lubuk Manik Kecamatan Rantau Pandan dapat disimpulkan sebagai berikut :

Tingkat Patisipasi masyarakat umum dengan melibatkan 80 orang responden untuk pengelolaan Kawasan Konservasi kategori rendah dengan nilai 1685 dalam persentase $(21,06 \%)$, Tingkat partisipasi Pemangku Kepentingan dengan jumlah responden sebanyak 20 orang responden dimana tingkat partisipasi dalam kategori rendah dengan nilai partisipasi sebesar 622 dengan persentase sebesar $(31,1 \%)$.

2. Saran 
SEMAH : Journal Pengelolaan Sumberdaya Perairan VOL. 3 No. 1

April 2019

1. Diperlukan sosialisasi menyeluruh dan berkelanjutan kepada masyarakat mengenai program program pemerintah khususnya tentang konservasi sumberdaya perikanan di wilayah Kecamatan Rantau Pandan .

2. Masyarakat diikutsertakan secara aktif dalam pelaksaan pengelolaan konservasi diwilayahnya masing - masing.

1. Pemerintah harus melaksanakan kegiatan program pengelolaan daerah konservasi seperti pemasangan tanda daerah lindung, pengawasan dan kegiatan yang mendukung seperti penebaran bibit ikan.

2. Diperlukan adanya kesinambungan program konservasi yang melibatkan secara aktif seluruh stakeholder (pemerintah pusat dan daerah serta nelayan). Selain itu perlu dibuat PERDA untuk menjamin keberadaan Kawasan Konservasi Perikanan (Reservat).

\section{DAFTAR PUSTAKA}

Ardimansyah.,2011. Konservasi sumberdaya perikanan di kecamatan Danau Panggang Kabupaten Hulu Sungai Utara. Jurnal Socioscientia Kopertis Wilayah XI Kalimantan.

, 2011. Potensi ekonomi ikan bujuk (Channa lucius) sebagai peluang calon ikan budidaya di perairan umum daratan. Prosiding Seminar Nasional Forum Perairan Umum
ojs.umb-bungo.ac.id/index-php/SEMAHJPSP ISSN : 2580-0736

Daratan Indonesia 26-27 September 2011 di Palembang.

Dinas Kelautan dan Perikanan Propinsi Jambi, 2015 Laporan Tahunan Kelautan dan perikanan propinsi jambi, Dinas kelautan dan perikanan Propinsi Jambi.

2015. Laporan Tahunan Statistik Perikanan Tangkap Dinas Peternakan dan Perikanan Kabupaten Bungo, Muara Bungo.

Kurniasari, N; M,Yulisti; C, Yuliaty., 2013. Lubuk Larangan : Bentuk Perilaku Ekologis Masyarakat Lokal Dalam Pengelolaan Sumber Daya Perikanan Perairan Umum Daratan. Jurnal Sosek Kelautan dan Perikanan Vol.8 no. 2 Tahun 2013

Nga, V.T.T. 2012. Evaluating the effectiveness of co-management in Nui Chua National Park Marine Protected Area Ninh Thuan Province, Vietnam. Master Thesis in Fisheries and Aquaculture Management and Economics FSK-3911 (30 ECTS). The Norwegian College of Fishery Science, University of Tromso, Norway \& Nha Trang University, Vietnam. 